\title{
The Use of Oxytocin Electrostimulator Corsets as A Preventive Measures of Postpartum Bleeding Potential
}

\author{
Ida Ayu Putu Dewi Adnya Suwari ${ }^{1}$, Runjati ${ }^{2}$, Djamaluddin Ramlan ${ }^{3}$ \\ \{dayuadnyasuwari@yahoo.com ${ }^{1}$, runjati@yahoo.com ${ }^{2}$, djamaluddinramlan@gmail.com ${ }^{3}$ \} \\ Poltekkes Kemenkes Semarang, Semarang, Indonesia ${ }^{1,2,3}$
}

\begin{abstract}
Postpartum hemorrhage can be prevented by administration of oxytocin. However, oxytocin electrostimulator corset was needed to keep uterus contracting effectively because of relatively short half-life of oxytocin. A quasiexperimental research design with time series was conducted at Gunung Sari Health Center, West Lombok, Indonesia on 40 giving birth women by consecutive sampling technique. The study objective was to determine oxytocin electrostimulator corsets effect on 24 hours postpartum maternal blood volume. There were differences in the average blood volume in 6 hours postpartum, 12 hours postpartum, 18 hours postpartum, 24 hours postpartum and total blood volume in 24 hours postpartum between control and intervention group $(p<0.05)$. However, the average bleeding volume was no difference between stage III and 2 hours postpartum. The use of oxytocin electrostimulator corset can reduce maternal blood volume within 24 hours postpartum. This research was expected as reference for the postpartum hemorrhage prevention.
\end{abstract}

Keywords: corset, electrostimulator, oxytocin, postpartum hemorrhage

\section{Introduction}

Postpartum hemorrhage is a blood disorder after a $500 \mathrm{ml}$ vaginal delivery[1] that causes an increased risk of infection, Sheehan's Syndrome and even failure of lactation[2-6]. Based on Meng's Chen et al., Research showed that message to the uterus combined with administration of oxytocin to MAK III care did not give effective added benefits and was not a step needed to prevent postpartum hemorrhage so that midwives could take time for other work[7]. Oxytocin also has a relatively short half-life of 4-10 minutes to keep the uterus steady. Effective contraction requires ongoing intervention[8]. In the research of Anggorowati et al., Showed that oxytocin stimulation can be done using engineered tools such as electrostimulators using Digital Massager of Oxytocin (DMO). DMOs can be practiced on postpartum mothers in any situation as long as they are conscious. DMO tools are simple, can be practiced independently and managed by themselves. The average oxytocin in postpartum women on the first day 
given DMO was $353.58 \mathrm{ng} / \mathrm{ml}$ and showed that the maternal oxytocin hormone was in the normal category[9]. The use of a tight back corset will put pressure on the abdominal so that when doing the movement will reduce intra-distal pressure to $30 \%$, so that the muscles of the lumbar will be more relaxed, so that spasm is reduced, muscle stability will be achieved.

\section{Subjects and Method}

\subsection{Study Design}

This type of research is a quasi-experimental research with a time series research design. This research was conducted in January-February 2020 at the Gunung Sari Health Center in West Lombok.

\subsection{Population and Sample}

The population in this study were all women giving birth at Gunung Sari Health Center, West Lombok Regency. The sample in this study were mothers who gave birth to vaginal birth at the Gunung Sari Health Center. Determination of the research sample is done by using consecutive sampling which is a way of taking samples by selecting samples that meet the research criteria until a certain period of time so that the number of samples is fulfilled. subject minimally met. Where respondents in odd order are grouped in the intervention group, while respondents in even order are grouped in the control group. The sample in this study was chosen based on the following criteria. a. Inclusion criteria

1) Mothers who are willing to be respondents

2) Mother giving birth vaginal

3) The mother does not have an allergy to the underpad and pads provided by the researcher

4) Mothers whose parity is $\leq 4$

b. Exclusion criteria

1) Women with complications that cause the need for operative measures such as vacuum, extraction of forceps or sectio caesarea.

2) Women who experience complications such as placental retention, uterine atony, uterine inversion, placental rest, uterine tears.

So the sample in the intervention group were 20 samples and the control group were 20 samples so that the total number of intervention and control samples was 40 samples.

\subsection{Study Variables}

The independent variable in this study was the back corset oxytocin electrostimulator in the intervention group compared with oxytocin message in the control group. While the dependent variable is maternal blood volume 24 hours postpartum. 


\subsection{Operational Definition of Variables}

The oxytocin electro stimulator back corset which is an independent variable is a therapeutic tool for stimulating oxytocin using low-frequency electricity at points BL 17 and BL 18 with a duration of 20 minutes which is packaged simply in the form of a back corset. Blood volume which is the dependent variable is blood volume measured from the third stage of labor until the first 24 hours postpartum. Blood volume is measured by calculating the difference in the wet and dry weight of the blood absorption media, where 1 gram is equal to $1 \mathrm{ml}$ of blood. Weighing blood volume with a digital scale and observing it with SOP's and observation sheets. Blood volume results in $\mathrm{ml}$ units with a ratio measurement scale. For age, parity and hemoglobin level, interviews were conducted using a questionnaire.

\subsection{Study Instruments}

This research was conducted using instruments in data collection such as:

1. Blood volume measuring devices with a digital scale with the brand DNG Kitchen Scale AB 01.

2. Respondent questionnaire that became the study sample.

3. Standard Operational Procedure (SOP) measurement of maternal blood volume 24 hours postpartum by gravimetric method.

4. Observation sheet 24-hour postpartum maternal blood volume measurement results.

5. Oxytocin electrostimulator back corset

The oxytocin electrostimulator back corset was modified from the MultiFunctional Dual-Output Massager Model JY-A818.

\subsection{Data analysis}

This univariate analysis looks at the frequency distribution of data: age, parity and hemoglobin levels. This analysis takes the form of a frequency distribution and then narrated by the results of research that has been done. The research data were tabulated for further analysis using SPSS for bivariate analysis. Prior to the analysis test, the data normality test was carried out using Sapiro Wilk and to decide the difference in average bleeding at each measurement time interval, the Independent Sample T-Test.

\subsection{Research Ethics}

This study pays attention to ethical aspects such as Informed Concent, Anonimity, Confidentaly, Equality, Benefecience, Respect of Human Dignity and Justice. This research was conducted after the Ethical Clearance proposed by researchers was approved by the Health Ethics Committee of the Mataram Health Polytechnic Number: LB.01.03 / 1.1 / 906 / 2020 on January 2, 2020. 


\section{Results}

\subsection{Sample Characteristics}

Table 1. Homogeneity Test Characteristics of Respondents

\begin{tabular}{|c|c|c|c|}
\hline \multirow[b]{2}{*}{ Variabel } & \multicolumn{2}{|c|}{ Kelompok } & \multirow[b]{2}{*}{$p$-value } \\
\hline & $\begin{array}{l}\text { Intervensi } \\
\text { Mean } \pm \text { SD }\end{array}$ & $\begin{array}{l}\text { Kontrol } \\
\text { Mean } \pm \text { SD }\end{array}$ & \\
\hline Age & $30,1 \pm 6,42$ & $26,55 \pm 6,32$ & 0,753 \\
\hline Parity & $2,60 \pm 1,046$ & $1,90 \pm 0,912$ & 0,275 \\
\hline Hemoglobin Levels & $12,05 \pm 0,821$ & $12,03 \pm 0,898$ & 0,402 \\
\hline
\end{tabular}

Based on table 1 about the characteristics of the respondents interpreted in the intervention group that is the most statistically aged at the ideal reproductive age of 2035 years as many as 16 people (80\%), while the control group more than 20-35 years as many as 17 people ( $85 \%)$. On parity characteristics, multiparity tended to be higher than primary found 17 people $(85 \%)$ in the intervention group while the control group 12 people $(60 \%)$. For the characteristics of dominant hemoglobin, respondents had HB $11-11.9 \%$ with a well-balanced number of 11 people (55\%) in the intervention and control groups.

Based on table 1 the average age is 30.1 years, parity 2 to 3 and $\mathrm{Hb}$ level is 12.05 $\mathrm{gr} \%$. The frequency distribution of the characteristics of the control group had an average age of 26.5 years, an average parity of 1 to 2 and a $\mathrm{Hb}$ level of $12.03 \mathrm{gr} \%$. After the levene test was carried out on the characteristics of age, parity and Hb levels, pvalue $>0.05$ means that the respondents of the two research groups were homogeneous, so it can be concluded that there were no differences in characteristics between the two groups.

\subsection{Bivariate Analysis}

Data normality test results of measurement of bleeding volume using ShapiroWilk due to the number of respondents $<50$, a data distribution is said to be normal if the value of $p>0.05$. This normality test uses SPSS version 16. Results of normality test data on total blood volume 24 hours postpartum on the third stage measurement, 2 hours postpartum, 6 hours postpartum, 12 hours postpartum, 18 hours postpartum, 24 hours postpartum and total blood volume and the difference in each measurement obtained p-value significance value $>0.05$ or normal distribution of data distribution, so to test the hypothesis used the Independent Sample T-Test. However, the measurement of 6 hours postpartum obtained a significance value of 0.015 (p-value <0.05) or distribution of data that was not normally distributed, then carried out a transformation of the data and obtained a significance value of 0.210 (p-value> 0.05 ) or normal distribution data so parametric test is carried out using the Independent Sample T-Test as well. To compare the $\mathrm{p}$-value of the bleeding volume between each group, the Independent Sample T-Test was performed which has been described in the table. In addition, it can be seen that maternal blood volume at 6 hours postpartum, 12 hours postpartum, 18 hours postpartum, 24 hours postpartum, and total maternal blood volume in 24 hours 
postpartum in the intervention and control groups obtained $\mathrm{p}$ values $<0.05$, which means Ho rejected. It can be concluded that there are differences in average maternal blood volume at 6 hours postpartum, 12 hours postpartum, 18 hours postpartum, 24 hours postpartum, and total maternal blood volume in 24 hours postpartum between the intervention group given the back corset oxytocin electrostimulator with the control group provided given oxytocin massage. The volume of bleeding in mothers who were given the back corset oxytocin electrostimulator had lower mean bleeding than those who were given oxytocin massage on each measurement. Measurement of maternal blood volume at stage III, 2 hours postpartum and the difference between the results of each measurement time interval obtained $p$ value $>0.05$, which means there is no difference in the decrease in maternal blood volume between the intervention group and the control group at stage III, 2 hours postpartum and the difference the results of each measurement time interval. The results of the measurement of bleeding volume in the first 24 hours postpartum in the intervention and control groups can be seen in Figure 4.1.

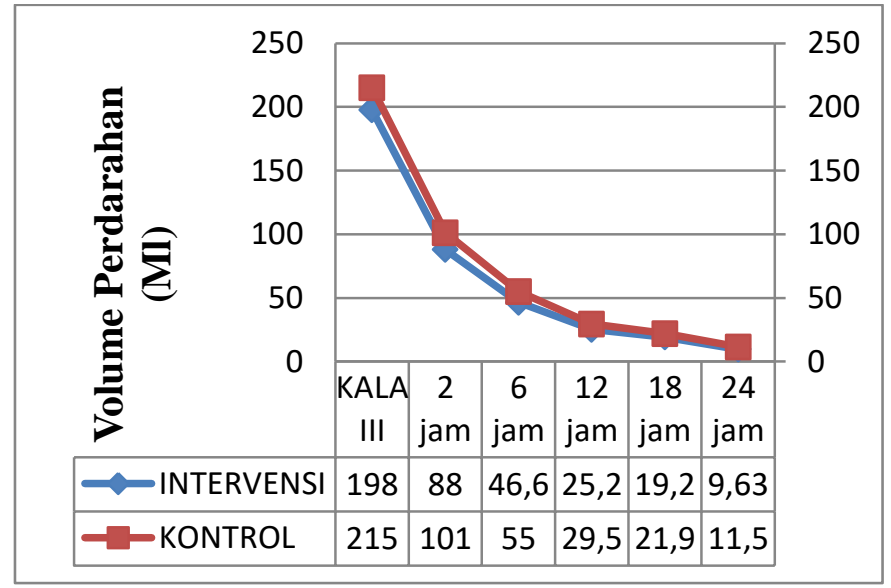

Fig. 1. Comparison of 24-hour bleeding volume Postpartum in the Intervention Group and Control group

Based on graph 4.1 above, it can be seen that the volume of bleeding in both groups experienced a significant downward trend starting from 2 hours postpartum and continuing to decrease to 24 hours postpartum. The average blood volume in the control group was higher than the average blood volume in the intervention group in each measurement. Blood volume tends to have a trend that decreases slowly until the next measurement.

The average total bleeding volume in the intervention group was $386.03 \mathrm{ml}$ with a minimum volume of $311.47 \mathrm{ml}$ and a maximum of $468.99 \mathrm{ml}$. The intervention group had lower average bleeding than the control group at each measurement. In the control group the average total bleeding volume was $434.25 \mathrm{ml}$ with a minimum volume of $327.81 \mathrm{ml}$ and a maximum of $507.78 \mathrm{ml}$. The bleeding volume at the first measurement is the most bleeding volume compared to the bleeding volume at other 
observation time intervals because the bleeding originates from the placental implantation site.

At 2 hours postpartum, the bleeding volume was reduced to $55.46 \%$ from the measurement at the third stage in the intervention group. Bleeding volume tends to experience a significant decrease in stage III towards 2 hours postpartum. At the next measurement at 6 hours postpartum, blood volume was reduced in the range of $47.07 \%$ from the previous measurement at 2 hours postpartum. At 12 hours blood volume was reduced in the range of $45.90 \%$ from measurements at 6 hours postpartum and at 18 hours blood volume was reduced at around $23.74 \%$ from previous measurements at 12 hours postpartum. At 24 hours postpartum bleeding decreased to $49.84 \%$ from the previous measurement in the intervention group.

The bleeding volume also continued to decrease slowly in the control group. At 2 hours postpartum, the bleeding volume decreased to $52.96 \%$ from the time of the third stage in the control group. Bleeding volume tends to experience a significant decrease in stage III towards 2 hours postpartum. At the next measurement at 6 hours postpartum, blood volume was reduced in the range of $45.66 \%$ from the previous measurement at 2 hours postpartum. At 12 hours blood volume was reduced in the range of $46.33 \%$ from measurements at 6 hours postpartum and at 18 hours blood volume was reduced considerably in the range of $25.66 \%$ from previous measurements at 12 hours postpartum. At 24 hours postpartum bleeding was reduced by $47.69 \%$ from the previous measurement in the control group.

The trend of blood volume in both groups has decreased. Blood volume continues to decrease slowly until the next measurement. This can be seen from the calculation of the difference in the measurement of blood volume at each time interval of observation. In the difference between the first measurement ie stage III and 2 hours postpartum there was a decrease in blood volume which was very much around $55.46 \%$ in the intervention group and $52.96 \%$ in the control group and in the 18 hours and 24 hours postpartum there was a decrease in blood volume around $49.84 \%$ in the intervention group and $47.69 \%$ in the control group. It can be concluded that the greatest decreasing trend in bleeding is in the intervention group given the back corset oxytocin electrostimulator.

\section{Discussion}

In this study, p-value> 0.05 showed that there was no difference in the average bleeding volume at stage III, 2 hours postpartum and the difference in blood volume at each interval of measurement time. At the time of the first measurement, the bleeding volume was relatively more than the following measurements because the blood vessels which were the source of bleeding were still open and in the third stage both the intervention group and the control group had not been given any intervention. As explained earlier that the source of bleeding in the normal delivery process comes from the former site of placental implantation and laceration of the birth canal which makes the two groups have an average blood volume that is not much different.

The average amount of bleeding after the placenta was given an injection of oxytocin was $185.5 \mathrm{ml}$ while the amount of bleeding that was not given oxytocin injection 
was $229.5 \mathrm{ml}$. In this study the amount of bleeding during the third stage in the intervention group was $197.5 \mathrm{ml}$ and the control group was $215.1 \mathrm{ml}$, where both groups were given oxytocin injection. The study of 10 women showed an increase in plasma oxytocin concentration after being given oxytocin at the time of birth of the placenta. In stage III there is a sudden reduction in metabolism due to the release of the placenta, where the placenta is the main source of oxytocin. As a result of the release of the placenta, the hypothalamus is stimulated to produce the hormone oxytocin. In addition, the hormone oxytocin can be produced through stimulation of oxytocin stimulation, one of which is by electrostimulator[10].

In this study blood volume at 2 hours postpartum obtained an average of $87.96 \mathrm{ml}$ intervention group and $101.17 \mathrm{ml}$ control group. There was no significant difference in maternal blood volume 2 hours postpartum between the intervention and control groups. This is because in the second measurement, the opened blood vessels have closed with uterine contractions and also stitching of the birth canal tear. As a result, there is a very significant decrease in bleeding volume in this second measurement. Naturally, the uterus will undergo a process called uterine involution in which the size of the uterus will gradually shrink in reference to its original size before pregnancy. This involution process occurs by making the uterus contract so that the opened blood vessels from the placental release gradually close and the bleeding decreases. The effectiveness of uterine contractions needs to be maintained because bleeding can occur at any time.33 This is in line with Chilmawati's[3] study that the amount of bleeding that is considered normal at stage 4 is $250 \mathrm{ml}$, usually $100-300 \mathrm{ml}$. This theory is strengthened by the results of Sarli et al's[11] study which states that the average amount of bleeding is $247.06 \mathrm{ml}$ and Rahmawati's study was $252.50 \mathrm{ml}$ in the control group who did not get any intervention at 2 hours postpartum[12].

In this study the results of blood volume measurement based on measurement time at 6 hours postpartum, 12 hours postpartum, 18 hours postpartum, 24 hours postpartum and total bleeding for 24 hours obtained $p$ value $<0.05$ which means that there are differences in all measurements in the intervention group and control group. Bleeding that was considered normal in the first 6 hours of postpartum was 1 bandage or as many menstrual blood came out. 8 In this study blood volume in the intervention group was $46.55 \mathrm{ml}$ and $54.97 \mathrm{ml}$ in the control group so the bleeding volume was still considered normal. In addition, it was also obtained the difference in value based on the time of measurement in each group where in the second measurement difference ie from 2 hours and 6 hours postpartum there was a very large decrease in blood volume around $55.46 \%$ in the intervention group and $52.96 \%$ in the group control. At measurements at 12 hours, 18 hours and 24 hours the volume of bleeding tends to decrease consistently at subsequent measurements. At 12 hours blood volume was reduced by a range of $45.90 \%$ from the 6 hour postpartum measurement and at 18 hours blood volume was reduced at around $23.74 \%$ from the previous measurement at 12 hours postpartum in the intervention group while for the control group at 12 hours the blood volume was reduced in the range of $46.33 \%$ from the measurement at 6 hours postpartum and at 18 hours the blood volume was reduced considerably in the range of $25.66 \%$ from the previous measurement at 12 hours postpartum. The reduction in blood volume is less because of 40 respondents there were 3 respondents in the intervention group and 3 respondents in the control group who experienced an increase in bleeding volume from 12 hours to 18 hours. 
An increase in the volume of bleeding in women who received standard care at certain observation time intervals even though it was not significant. Postpartum hemorrhage that causes death is not always bleeding at once in large quantities but can occur little by little but continuously the amount sometimes does not cause suspicion. Three out of five cases of maternal death due to bleeding are caused by suboptimal routine observations during the puerperium, therefore, the patient needs to be observed closely, appropriate action is taken immediately and the diagnosis is made early[8].

At 24 hours postpartum bleeding decreased to $49.84 \%$ from the previous measurement in the intervention group and reduced to $47.69 \%$ from the previous measurement in the control group. This shows that the application of the oxytocin electrostimulator back corset can reduce the volume of postpartum hemorrhage because it is able to keep the uterus contracting effectively as research results by Anggorowati et al., Which states that the average oxytocin in postpartum women on the first day is $353.58 \mathrm{ng} / \mathrm{ml}$ engineered oxytocin stimulation such as Digital Massager of Oxytocin (DMO) shows that the maternal oxytocin hormone is in the normal category[10]. In addition, 24 hours postpartum the mother has mobilized to facilitate blood flow into the uterus so that uterine contractions will be good and uterine fundus will become hard and smooth out blood and residual placenta. Where early mobilization is an immediate activity that is carried out as soon as possible after a few hours of rest by moving from the mother's bed in normal labor.

The average total bleeding volume in the intervention group that was given an oxytocin electrostimulator back corset was $386.03 \mathrm{ml}$ with a minimum bleeding volume of $311.47 \mathrm{ml}$ and a maximum of $468.99 \mathrm{ml}$. The average total bleeding volume in the control group was $432.25 \mathrm{ml}$ with a minimum bleeding volume of $327.81 \mathrm{ml}$ and a maximum of $507.78 \mathrm{ml}$. The intervention group had an average lower total bleeding volume than the control group that could be affected by the respondent's age, parity and $\mathrm{Hb}$ levels at delivery.

Based on table 4.1 regarding the characteristics of respondents interpreted in the intervention group has an average age of 30.1 years and the control group has an average age of 26.5 years. Age at risk ( $<20$ years or $>35$ years) has a 3.7 times greater risk of experiencing postpartum hemorrhage than mothers who are not at risk (20 to 35 years). The safest age is between 20 - 35 years because at that time the woman was in a healthy reproductive period [13]. In addition, in this study the average parity in the intervention group 2 to 3 and the control group had an average parity of 1 to 2 . The magnitude of risk 2,4 times greater parity at risk ( 1 or $>3$ ) to experience postpartum hemorrhage than parity at no risk (2 - 3) [13]. Parity greater than 4 has uterine muscle stretched more frequently so that the walls are thinner and contractions are weaker [14]. Mothers giving birth with Low $\mathrm{Hb}$ can decrease $\mathrm{Hb}$ faster if bleeding occurs. In this study, the average $\mathrm{Hb}$ level was $12.05 \mathrm{gr} \%$ in the intervention group and the $\mathrm{Hb}$ level was $12.03 \mathrm{gr} \%$ in the control group. Anemic maternal women have a risk of 17.6 times for postpartum hemorrhage compared to mothers who are not anemic because of uterine disability which is a direct cause of atonia [15].

This study is in line with the results of Diah et al's study in which 24-hour total bleeding volume in the $509.80 \mathrm{ml}$ intervention group was given acupressure and moxibustion while $596.65 \mathrm{ml}$ in the control group was only given acupressure only. However, the results of his study show that the combination of acupressure and moxibus- 
tion can reduce the volume of blood loss at each interval of observation but cannot prevent postpartum hemorrhage that occurs immediately after birth of the placenta [8].

In addition, the difference in decrease in blood volume with a p-value> 0.05 was obtained which showed no difference in the decrease in blood volume between the intervention group and the control group at each time interval of measurement. Where the intervention group had a difference in a decrease in blood volume higher than the control group. However, the uterus will naturally undergo a process called uterine involution in which the size of the uterus will gradually shrink to its original size before becoming pregnant. This involution process occurs by making the uterus contract so that the blood vessels that open due to the release of the placenta gradually close and the bleeding decreases. The effectiveness of uterine contractions needs to be maintained because bleeding can occur at any time [8].

Massage stimulation using an electrostimulator back corset will trigger contraction of smooth muscle in the uterus. Actin and myosin bonds are strengthened by the release of the hormone oxytocin so that uterine contractions get stronger and the process of uterine involution is better. The hormone oxytocin compresses blood vessels and helps the process of hemostasis. The contractions and retractions of the uterine muscles also reduce the blood supply to the uterus. This process helps reduce placental implantation scars and reduces bleeding [16]. Back corsets are also able to support the back and abdominal muscles after pregnancy and offer comfort to the mother, help shrink the uterus, pull back the abdominal wall muscles and reduce the space for fat deposits. Postpartum mothers who wear corsets can get a little compression in the abdominal tranversus muscle so that it supports the abdomen and lumbopelvic region [17].

The results of this study are in line with research conducted by Cunningham that the abdominal wall muscles function as a stabilizer (brace) so that the force reaching the abdominal wall will be reflected back and will increase intra-abdominal pressure and then will increase the thrust into the uterine cavity. This is what drives lochea fluid out through the vagina, a decrease in the uterine fundus and a good uterine involution process [18]. In addition, the back corset oxytocin electrostimulator uses a spikeexponential monophase pulse shape having an effective voltage that is much smaller than its peak voltage. This causes the effective current produced by the electrostimulator to be small, so that it can meet the safety standards of medical instrumentation [19]. In addition, this tool has a DC voltage of 4.5 volts which is included in the normal range because at this voltage the impulse response is relatively stable [20] because when the energy level is given above the threshold energy there is an overall action potential, but if the energy is below the threshold energy there is no action potential [13].

On the back corset the oxytocin electrostimulator frequency setting is related to the purpose of the use of electrostimulator [20]. The recommended setting that can be used is the high frequency of $100 \mathrm{~Hz}$ [21], and this tool has a frequency of $1-330 \mathrm{~Hz}$ which can be adjusted according to patient needs. This electrostimulator also complies with medical device safety standards by having an effective current below $5 \mathrm{~mA}$ because the higher the amplitude given means that also increases the electrical energy sent into the body [19]. 


\section{Conclusion}

The use of oxytocin electrostimulator back corset as an effort to prevent the potential for postpartum hemorrhage that has been described, it can be concluded that there are differences in maternal blood volume at 6 hours postpartum, 12 hours postpartum, 18 hours postpartum, 24 hours postpartum and total blood volume in 24 hours postpartum in the intervention group and the control group with a $p$-value $<0.05$ with the average blood volume of the intervention group lower than the control group at each measurement time interval.

\section{$6 \quad$ Financial Support and Sponsorship}

There was no financial support and sponsorship.

\section{$7 \quad$ Conflict of Interest} closed.

The authors state explicitly that there are no conflicts of interest to be dis-

Acknowledgement We would like to thank Postgraduate Applied Science Program in Midwifery, Poltekkes Kemenkes Semarang.

\section{References}

[1] Lutomski JE, Byrne BM, Devane D, Greene RA. Increasing trends in atonic postpartum haemorrhage in Ireland: An 11-year population-based cohort study. BJOG An Int J Obstet Gynaecol 2012;119:306-14.

[2] Maria R, Volpato J, Asse P, Luzı E, Asse V, Fernanda M et al. Components of breast milk. J Matern Neonatal Med 2013;26:1223-7.

[3] Chilmawati L, Pradjatmo H, Siswosudarmo HR. Pengaruh pemberian asam traneksamat terhadap jumlah perdarahan pascasalin pada kelahiran vaginal. J Kesehat Reproduksi 2014;1:98-102.

[4] Abdul-Kadir R, McLintock C, Ducloy AS, El-Refaey H, England A, Federici AB, et al. Evaluation and management of postpartum hemorrhage: Consensus from an international expert panel. Transfusion 2014;54:1756-68.

[5] Wang F, Li C, Li S, Li Q. Integrated interventions for improving negative emotions and stress reactions of young women receiving total hysterectomy. Int J Clin Exp Med 2014;7:331-6.

[6] Karaca Z, Laway BA, Dokmetas HS, Atmaca H, Kelestimur F. Sheehan syndrome. Nat Publ Gr 2016;2:1-15.

[7] Chen M, Duan T. Uterine massage to reduce blood loss after vaginal delivery 2013;122:290-5.

[8] Mesayu diah kurniawati. Efektivitas akupresur dan moksibusi terhadap penurunan perdarahan dalam 24 jam pertama pascasalin. poltekkes kemenkes semarang, 2019.

[9] Anggorowati A, Sutadi H, Setyowati S, Koestoer RA. Effects of acupoint stimulation with digital massager of oxytocin on the breast milk production of working mothers. 
Nurse Media J Nurs 2017;6:91.

[10] Anggorowati A, Susilowati D, Zubaidah. Effects of engineered stimulation of oxytocin on hormonal status of postpartum women. Hiroshima J Med Sci 2018;67:91-6.

[11] Sarli D, Agus M. Artikel penelitian pengaruh perbedaan kadar oksitosin melalui pemijatan oksitosin terhadap jumlah perdarahan pada ibu 2 jam postpartum. J Kesehat Andalas 2014;4:743-50.

[12] Rahmawati WR, Arifah S, Widiastuti A. Pengaruh pijat punggung terhadap adaptasi nyeri persalinan fase aktif lama kala II dan perdarahan persalinan pada primigravida. Kesmas Natl Public Heal J 2013;8:204.

[13] Ummah N, Ngadiyono N, Ulfiana E. Faktor resiko penyebab perdarahan postpartum di puskesmas pamotan kabupaten rembang. J Kebidanan 2018;7:39.

[14] Yekti Satriyandari NRH. Faktor-faktor yang mempengaruhi kejadian perdarahan postpartum. J Heal Stud 2014;1:49-64.

[15] Psiari Kusuma W. Faktor-faktor yang mempengaruhi terjadinya perdarahan postpartum. J Ilmu Kesehat 2017;2:51-60.

[16] Meintri Lanasari N, Rahayu S, Panggayuh A. Pengaruh pijat endorphin terhadap percepatan involusi uteri pada ibu nifas post sectio caesarea. J Ilm Bidan 2018;III:15.

[17] Benjamin DR, van de Water ATM, Peiris CL. Effects of exercise on diastasis of the rectus abdominis muscle in the antenatal and postnatal periods: A systematic review. Physiother (United Kingdom) 2014;100:1-8.

[18] Sumarah, Mohammad Hakimi SP. Pengaruh inisiasi menyusu dini terhadap jumlah perdarahan pasca persalinan. J Kesehat Reproduksi 2014;1:60-9.

[19] Hutomo AP, Astuti SD. Rancang bangun sistem pengendali tegangan stimulasi elektrostimulator otomatis berbasis resistansi tubuh. J Biosains Pascasarj 2018;20.

[20] Evrita LU, Irawadi B, I Made GGP. Simulasi alat elektrostimulator akupuntur berbasis mikrokontroler ATMega16. J Ilmiah, Tek Elektro, Fak Sains Teknol Univ Respati Yogyakarta, Yogyakarta 2017;23:29-42.

[21] Báez-Suárez A, Martín-Castillo E, García-Andújar J, García-Hernández JÁ, QuintanaMontesdeoca MP, Loro-Ferrer JF. Evaluation of different doses of transcutaneous nerve stimulation for pain relief during labour: A randomized controlled trial. Trials 2018;19:1-10. 